УДК 538.955

\title{
Crystal Structure and Magnetic Properties in Pyroxenes $\mathrm{Li}_{0.7} \mathrm{Na}_{0.3} \mathrm{FeGe}_{2} \mathrm{O}_{6}$
}

Tamara V. Drokina*

German A. Petrakovskii ${ }^{\dagger}$

Kirensky Institute of Physics SB RAS

Akademgorodok, 50/38, Krasnoyarsk, 660036

Russia

Dmitrii A. Velikanov ${ }^{\ddagger}$

Kirensky Institute of Physics SB RAS Akademgorodok, 50/38, Krasnoyarsk, 660036

Siberian Federal University

Svobodny, 79, Krasnoyarsk, 660041

Russia

Maxim S. Molokeev $^{\S}$

Kirensky Institute of Physics SB RAS Akademgorodok 50/38, Krasnoyarsk, 660036

Far Eastern State Transport University

Serysheva, 47, Khabarovsk, 680021

Russia

Elena G. Rezina

Siberian Federal University

Svobodny, 79, Krasnoyarsk, 660041

Russia

Received 05.05.2015, received in revised form 08.06.2015, accepted 02.07.2015

The $\mathrm{Li}_{0,7} \mathrm{Na}_{0,3} \mathrm{FeGe}_{2} \mathrm{O}_{6}$ solid solution has been synthesized by the solid-phase reaction. The clinopyroxene compound has been investigated by X-ray diffraction and by bulk magnetic measurements. The structural properties of the cation substitution compound are presented. Using SQUID techniques the temperature dependence of the magnetic susceptibility was measured. It exhibits a sharp maximum, which is suggested the phase transition from the paramagnetic state to a magnetically ordered state below $15.5 \mathrm{~K}$ in the sample of pyroxene solid solution.

Keywords: solid solution, pyroxene, crystal structure, magnetic properties.

DOI: 10.17516/1997-1397-2015-8-3-273-280

\footnotetext{
*tvd@iph.krasn.ru

† gap@iph.krasn.ru

$\ddagger$ dpona@rambler.ru

§msmolokeev@mail.ru

『prim67@mail.ru

(c) Siberian Federal University. All rights reserved
} 


\section{Introduction}

Pyroxene inorganic compounds with the general chemical formula $\mathrm{ABX}_{2} \mathrm{O}_{6}(\mathrm{~A}=\mathrm{Na}, \mathrm{Li}$ and $\mathrm{Ca} ; \mathrm{B}=\mathrm{Mg}, \mathrm{Cr}, \mathrm{Cu}, \mathrm{Ni}$, Fe, etc.; $\mathrm{X}=\mathrm{Ge}, \mathrm{Si}$ ) have significant interest in solid state physics due to their physical properties. Magnetic studies have been carried out for the family pyroxenes compound: there are various types of magnetic state (antiferromagnetic [1-4], ferromagnetic [3-5], modulated magnetic structure [6,7], spin gap state [8]) connected to the features of the pyroxene crystal structure which allows the existence of competing magnetic exchange interactions.

Characteristic feature of the iron pyroxene $\mathrm{AFe}^{3+} \mathrm{X}_{2} \mathrm{O}_{6}$ crystal structure is the isolated chains $\mathrm{FeO}_{6}$ octahedra running along the c axis (Fig. 1) [9]. Magnetic interaction between the chains $(\mathrm{Fe}-\mathrm{O}-\mathrm{Ge}(\mathrm{Si})-\mathrm{O}-\mathrm{Fe})$ is weakened due to the presence of non-magnetic $\mathrm{Ge}(\mathrm{Si}) \mathrm{O}_{4}$ tetrahedra. Type of magnetic structure depends critically on the geometric topologies of the atomic structure which is determined the ratio of the intrachain $(\mathrm{Fe}-\mathrm{O}-\mathrm{Fe})$ and interchain $(\mathrm{Fe}-\mathrm{O}-\mathrm{X}-\mathrm{O}-\mathrm{Fe})$ exchange interactions parameters.

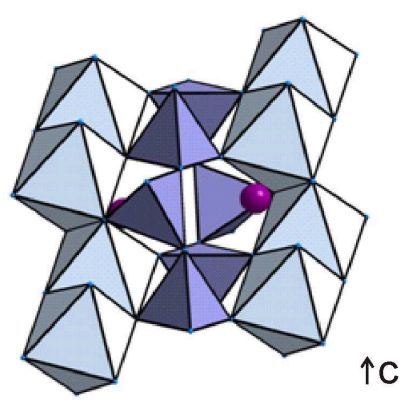

Fig. 1. Crystal structure of $\mathrm{AFeX}_{2} \mathrm{O}_{6}$ compounds: two chains of $\mathrm{FeO}_{6}$ octahedra and its connections via $\mathrm{Ge}(\mathrm{Si}) \mathrm{O}_{4}$ tetrahedra [9]. Balls represent $\mathrm{Na}(\mathrm{Li})$ ions

The $\mathrm{NaFeGe}_{2} \mathrm{O}_{6}$ and $\mathrm{LiFeGe}_{2} \mathrm{O}_{6}$ clinopyroxene-type germinates compounds exhibit different crystal and magnetic structures. The room temperature crystal structure of $\mathrm{LiFeGe}_{2} \mathrm{O}_{6}$ is monoclinic with space group $P 2_{1} / c$ [10]. The room temperature crystal structure of $\mathrm{NaFeGe}_{2} \mathrm{O}_{6}$ is monoclinic with space group $C 2 / c$ [11].

Structures of magnetic subsystem are quasi-one-dimensional in $\mathrm{AFeGe}_{2} \mathrm{O}_{6}$ compounds [9]. The magnetic structure of $\mathrm{LiFeGe}_{2} \mathrm{O}_{6}$ pyroxene is described to have an antiferromagnetic arrangement of spins within and between the octahedral $\mathrm{B}$ chains $\left(\mathrm{T}_{\mathrm{N}}=20.5 \mathrm{~K}\right)[2] . \mathrm{NaFeGe}_{2} \mathrm{O}_{6}$ characterized by Néel temperature $\mathrm{T}_{\mathrm{N}}=13 \mathrm{~K}$, below $\mathrm{T}=11.5 \mathrm{~K}$ the incommensurate magnetic structure with a helical spin modulation is realized $[6,12]$.

In this way, the possibility to synthesize the $\mathrm{LiFeGe}_{2} \mathrm{O}_{6}$ and $\mathrm{NaFeGe}_{2} \mathrm{O}_{6}$ solid solution is discovered the interesting physical properties. We have recently studied the crystal and magnetic structures of the $\mathrm{Na}_{0.5} \mathrm{Li}_{0.5} \mathrm{FeGe}_{2} \mathrm{O}_{6}$ compound [13]. The room crystal structure of $\mathrm{Na}_{0.5} \mathrm{Li}_{0.5} \mathrm{FeGe}_{2} \mathrm{O}_{6}$ is monoclinic $C 2 / c$ (high temperature parameters of the cell: $a=10.0333(1)$, $\left.b=8.8136(1), c=5.5295(9) \AA, \beta=108.921(1)^{\circ}\right)$. Calorimetric investigations indicate a displacive first order phase transition at $\mathrm{T}=276 \mathrm{~K}$, and at temperature decreasing $\mathrm{Na}_{0.5} \mathrm{Li}_{0.5} \mathrm{FeGe}_{2} \mathrm{O}_{6}$ undergoes a space group change from $C 2 / c$ to $P 2_{1} / c$ (low temperature parameters of the cell: $a$ $\left.=9.9692(3), b=8.8545(3), c=5.4752(2) \AA, \beta=108.494(1)^{\circ}\right)$. Magnetic order has been found below the Néel temperature $\mathrm{T}_{\mathrm{N}} \approx 18 \mathrm{~K}$ and has been refined from neutron diffraction. The quasilow-dimensional magnetic spin system $\mathrm{Na}_{0.5} \mathrm{Li}_{0.5} \mathrm{FeGe}_{2} \mathrm{O}_{6}$ exhibits a collinear antiferromagnetic 
structure with the space group $P_{a} 2_{1} / c$ and the doubling of the unit cell along the crystallographic $a$-axis of the pyroxene crystal (propagation vector $\boldsymbol{k}=(1 / 2,0,0)$ ).

No magnetic properties and a detailed crystal structure data are available for germinate clinopyroxene-type solid solution compound $\mathrm{Li}_{0.7} \mathrm{Na}_{0.3} \mathrm{FeGe}_{2} \mathrm{O}_{6}$. In the present contribution in pyroxenes research we report the experimental data on the room crystal structure and magnetic characteristics of the synthesized solid solution $\mathrm{Li}_{0.7} \mathrm{Na}_{0.3} \mathrm{FeGe}_{2} \mathrm{O}_{6}$.

\section{Sample preparation and experimental procedure}

Polycrystalline sample of solid solution $\mathrm{Li}_{0.7} \mathrm{Na}_{0.3} \mathrm{FeGe}_{2} \mathrm{O}_{6}$ was synthesized by a solid-phase reaction method from the stoichiometric mixture of oxides $\mathrm{GeO}_{2}, \mathrm{Fe}_{2} \mathrm{O}_{3}, \mathrm{Na}_{2} \mathrm{CO}_{3}, \mathrm{Li}_{2} \mathrm{CO}_{3}$

$$
2.00 \mathrm{GeO}_{2}+0.50 \mathrm{Fe}_{2} \mathrm{O}_{3}+0.15 \mathrm{Na}_{2} \mathrm{CO}_{3}+0.35 \mathrm{Li}_{2} \mathrm{CO}_{3} \rightarrow \mathrm{Li}_{0.7} \mathrm{Na}_{0.3} \mathrm{FeGe}_{2} \mathrm{O}_{6}+\mathrm{CO}_{2} .
$$

The mixture of the oxides was ground under ethanol, pressed into pellets and fired under ambient pressure at temperatures of $800-1000^{\circ} \mathrm{C}$ in air at three stages each with duration of $24 \mathrm{~h}$ with intermediate regrinding. At each heating stage the samples were slowly cooled to room temperature, ground and pressed into pellets for next heat treatment. The prepared pellets were pale brown. The chemical and phase composition of the pellet milled into the powder was examined by X-ray diffraction and shows a single phase.

The X-ray powder diffraction data of $\mathrm{Li}_{0.7} \mathrm{Na}_{0.3} \mathrm{FeGe}_{2} \mathrm{O}_{6}$ for Rietveld analysis was collected at room temperature with a Bruker D8 ADVANCE powder diffractometer ( $\mathrm{Cu}-\mathrm{K} \alpha$ radiation) and linear VANTEC detector. Refinement of the powder pattern was performed with TOPAS 4.2 (Bruker) [14].

A SQUID magnetometer operating from $300 \mathrm{~K}$ to $4 \mathrm{~K}$ at magnetic field 500 Oe was used to perform the dc magnetic measurements.

\section{Experimental results and discussion}

The X-ray powder diffraction pattern at $300 \mathrm{~K}$ reveals that $\mathrm{Li}_{0.7} \mathrm{Na}_{0.3} \mathrm{FeGe}_{2} \mathrm{O}_{6}$ has the centrosymmetric $C 2 / c$ space group with 4 formula units per the unit cell and the lattice parameters are close to those of $\mathrm{NaFeGe}_{2} \mathrm{O}_{6}[7,11]$. Therefore the crystal structure of $\mathrm{NaFeGe}_{2} \mathrm{O}_{6}$ was used as the starting structural model for the Rietveld refinement of the room temperature crystal structure of $\mathrm{Li}_{0.7} \mathrm{Na}_{0.3} \mathrm{FeGe}_{2} \mathrm{O}_{6}$. The site of $\mathrm{Na}$ ion was occupied by $\mathrm{Li}$ and $\mathrm{Na}$ ions with fixed occupation $\mathrm{p}_{\mathrm{Li}}=0.5$ and $\mathrm{p}_{\mathrm{Na}}=0.5$ respectively. The refinement was stable and gave low R-factors (Tab. 1, Fig. 2). Main parameters of refinement are shown in Tab. 1.

To obtain information on the magnetic properties of polycrystalline sample material of $\mathrm{Li}_{0.7} \mathrm{Na}_{0.3} \mathrm{FeGe}_{2} \mathrm{O}_{6}$ compound the dc magnetic measurements were perform. Magnetic properties are determined by $\mathrm{Fe}^{3+}$ ions as a $3 d^{5}$. The measured temperature dependence of the magnetic susceptibility in an external magnetic field of $\mathrm{H}=500$ Oe of monophased powder $\mathrm{Li}_{0.7} \mathrm{Na}_{0.3} \mathrm{FeGe}_{2} \mathrm{O}_{6}$ is shown in Fig. 3a. The magnetic susceptibility $\chi(\mathrm{T})$ of $\mathrm{Li}_{0.7} \mathrm{Na}_{0.3} \mathrm{FeGe}_{2} \mathrm{O}_{6}$ exhibits a sharp maximum at $24.8 \mathrm{~K}$ in its temperature dependence with the point of inflection being located at $15.5 \mathrm{~K}$. This behavior is usually related to a phase transition from the paramagnetic to the magnetically ordered state. Note, the pyroxene reported here the diamagnetic contribution in the magnetic susceptibility is negligible (Fig. $3 \mathrm{~b}$ ). 
Table 1. Main parameters of crystal structure refinement in $\mathrm{Li}_{0.7} \mathrm{Na}_{0.3} \mathrm{FeGe}_{2} \mathrm{O}_{6}$ at $300 \mathrm{~K}$

\begin{tabular}{|c|c|}
\hline Space group & $C / 2 c$ \\
\hline$a_{i}, \AA$ & $10.02346(11)$ \\
\hline$b_{i}, \AA$ & $8.80980(9)$ \\
\hline$c_{i}, \AA$ & $5.52550(6)$ \\
\hline$\beta,{ }^{\circ}$ & $108.9286(6)$ \\
\hline$V, \AA^{3}$ & $461.54(1)$ \\
\hline$D_{x}, \mathrm{~g} / \mathrm{cm}^{3}$ & 4.445 \\
\hline$Z$ & 4 \\
\hline Angle range $2 \theta$, deg. & $5-140$ \\
\hline Number of reflections & 4391 \\
\hline Number of refined parameters & 71 \\
\hline$R_{\text {wp }}, \%$ & 2.155 \\
\hline$R_{\mathrm{p}}, \%$ & 1.643 \\
\hline$\chi^{2}$ & 1.450 \\
\hline$R_{\mathrm{B}}, \%$ & 1.333 \\
\hline
\end{tabular}

Designations: $a, b, c$, and $\beta$ are the unit cell parameters; $V$ is the unit cell volume; $R_{\mathrm{B}}, R_{\mathrm{wp}}, R_{\mathrm{p}}$ are the integrated (Bragg), weighted profile and profile factors, respectively; and $\chi^{2}$ is the goodness-of-fit.

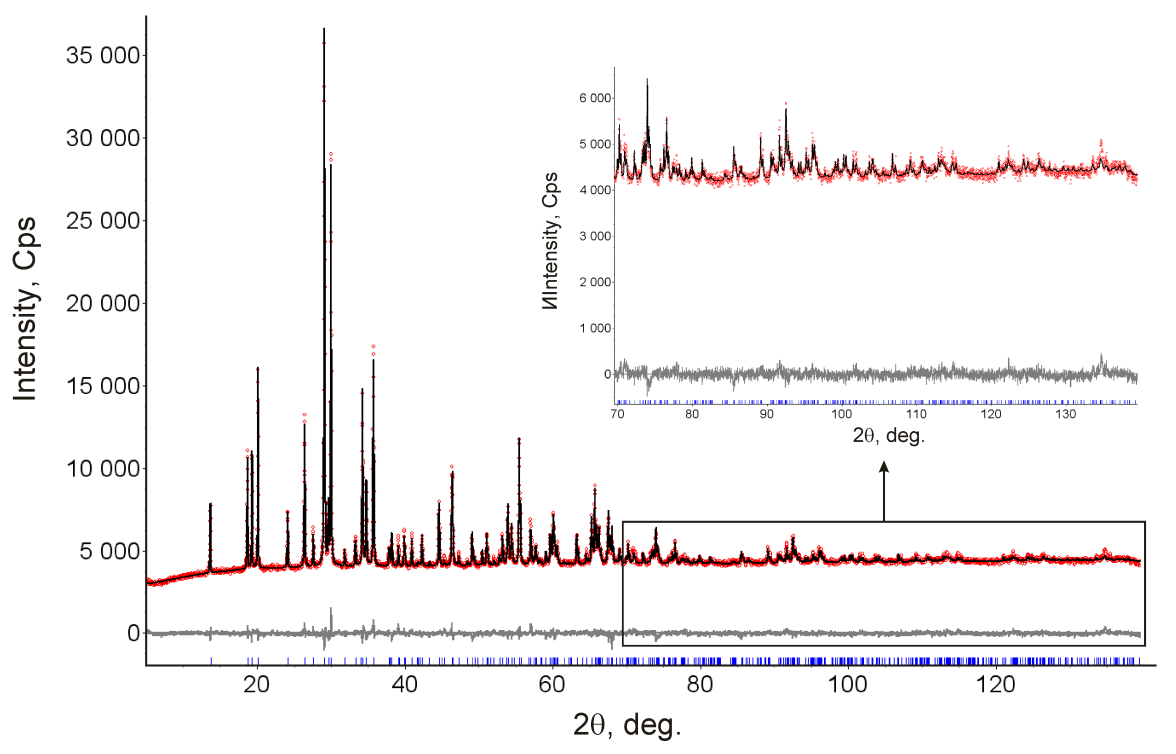

Fig. 2. Experimental (symbols), theoretical (line), and difference (lower line) X-ray powder diffraction pattern resulting from the Rietveld refinement of $\mathrm{Li}_{0.7} \mathrm{Na}_{0.3} \mathrm{FeGe}_{2} \mathrm{O}_{6}$ at $300 \mathrm{~K}$ 


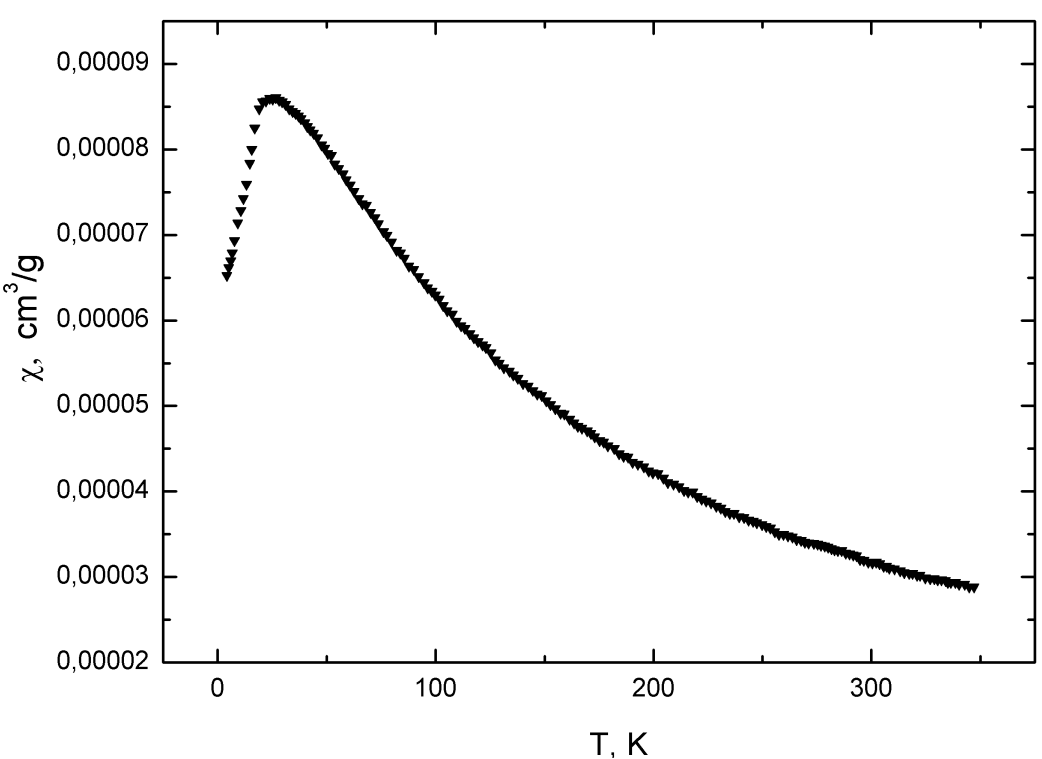

a)

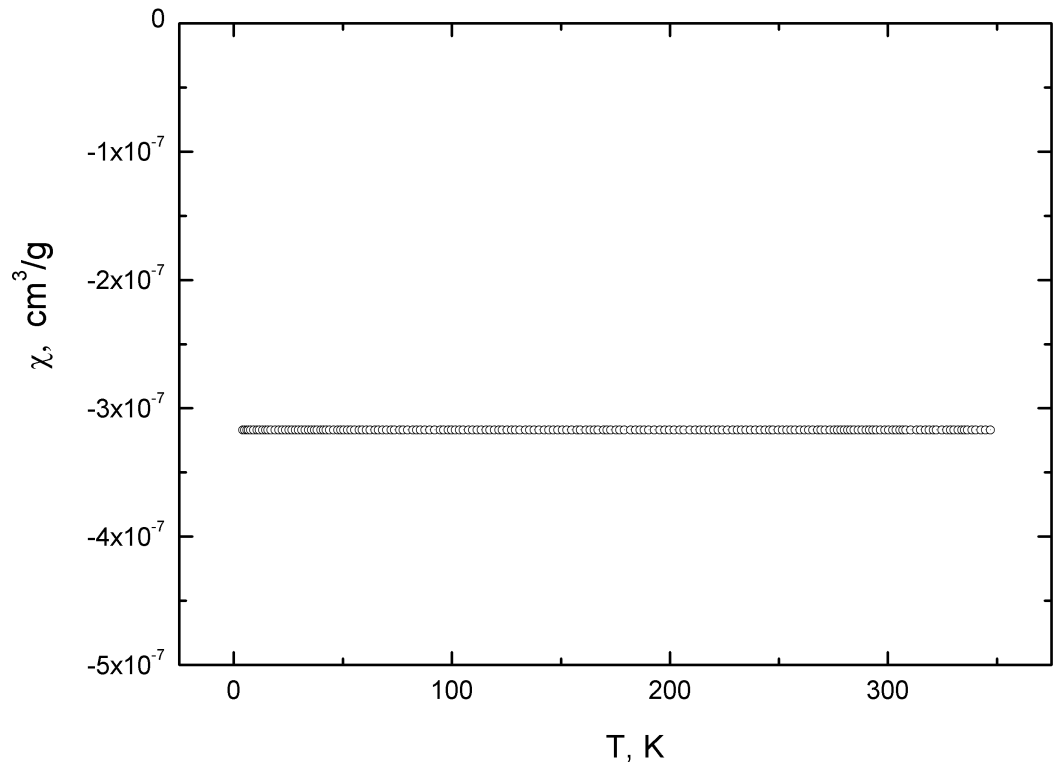

b)

Fig. 3. Temperature dependence of the magnetic susceptibility, obtained in $\mathrm{Li}_{0.7} \mathrm{Na}_{0.3} \mathrm{FeGe}_{2} \mathrm{O}_{6}$ sample: the total magnetic susceptibility (a) and the diamagnetic contribution in the magnetic susceptibility (b)

In order to compare some details between $\mathrm{NaFeGe}_{2} \mathrm{O}_{6}, \mathrm{LiFeGe}_{2} \mathrm{O}_{6}, \mathrm{Na}_{0.5} \mathrm{Li}_{0.5} \mathrm{FeGe}_{2} \mathrm{O}_{6}$ and $\mathrm{Li}_{0.7} \mathrm{Na}_{0.3} \mathrm{FeGe}_{2} \mathrm{O}_{6}$ samples we summaries the room crystal structure and magnetic parameters in the Tabs. 2,3 . 
Note, all materials of pyroxenes compound family $\mathrm{Na}_{x} \mathrm{Li}_{1-x} \mathrm{FeGe}_{2} \mathrm{O}_{6}(x=1,0.5,0.3$ and 0$)$ are monoclinic. End members $(x=0,1)$ exhibit different space group of crystal structure $\left(P 2_{1} / c, C 2 / c\right)$. Intermediate compositions $(x=0.5,0.3)$ exhibit $C 2 / c$ space group at $\mathrm{T}=$ $300 \mathrm{~K}$. It is interesting to examine the A cation substitution influences on magnetic properties too. In this solid solution the substitution $\mathrm{Li}^{+}$ions by $\mathrm{Na}^{+}$ions led to an increase in the lattice parameters and change the picture of the competing magnetic exchange interactions in the pyroxenes $\mathrm{Na}_{x} \mathrm{Li}_{1-x} \mathrm{FeGe}_{2} \mathrm{O}_{6}$ compound.

Table 2. Summary of the monoclinic crystal structure parameters for different pyroxene-type compounds at room temperature

\begin{tabular}{|c|c|c|c|c|c|c|}
\hline Sample & $a_{i}, \AA$ & $b_{i}, \AA$ & $c_{i}, \AA$ & $\beta,^{o}$ & $\begin{array}{c}\text { Space } \\
\text { group }\end{array}$ & Reference \\
\hline $\mathrm{NaFeGe}_{2} \mathrm{O}_{6}$ & 10.0100 & 8.9400 & 5.5200 & 108.0000 & $C / 2 c$ & {$[11]$} \\
\hline $\mathrm{Na}_{0.5} \mathrm{Li}_{0.5} \mathrm{FeGe}_{2} \mathrm{O}_{6}$ & $10.0333(1)$ & $8.8136(1)$ & $5.5295(9)$ & $108.921(1)$ & $C / 2 c$ & {$[13]$} \\
\hline $\mathrm{Li}_{0.7} \mathrm{Na}_{0.3} \mathrm{FeGe}_{2} \mathrm{O}_{6}$ & $10.02346(11)$ & $8.80980(9)$ & $5.52550(6)$ & $108.9286(6)$ & $C / 2 c$ & this study \\
\hline $\mathrm{LiFeGe}_{2} \mathrm{O}_{6}$ & $9.8792(7)$ & $8.8095(5)$ & $5.3754(3)$ & $108.844(6)$ & $P / 2_{1} c$ & {$[10]$} \\
\hline
\end{tabular}

Table 3. Summary of the magnetic parameters for different pyroxene-type compounds

\begin{tabular}{|c|c|c|c|}
\hline Sample & $\mathrm{T}_{\mathrm{N}}, \mathrm{K}$ & $\mathrm{T}_{\max }, \mathrm{K}$ & Reference \\
\hline $\mathrm{NaFeGe}_{2} \mathrm{O}_{6}$ & 13 & 25 & {$[12,15]$} \\
\hline $\mathrm{LiFeGe}_{2} \mathrm{O}_{6}$ & 20.2 & 24.4 & {$[2]$} \\
\hline $\mathrm{Na}_{0.5} \mathrm{Li}_{0.5} \mathrm{FeGe}_{2} \mathrm{O}_{6}$ & 18 & 27.5 & {$[13]$} \\
\hline $\mathrm{Li}_{0.7} \mathrm{Na}_{0.3} \mathrm{FeGe}_{2} \mathrm{O}_{6}$ & 15.5 & 24.8 & this study \\
\hline
\end{tabular}

\section{Conclusion}

The solid solution clinopyroxene compound $\mathrm{Li}_{0.7} \mathrm{Na}_{0.3} \mathrm{FeGe}_{2} \mathrm{O}_{6}$ was synthesized by solid-phase reaction. The chemical and phase composition of clinopyroxenes compound was examined by $\mathrm{X}$-ray diffraction and shows a single phase. The room crystal structure and magnetic properties of $\mathrm{Li}_{0.7} \mathrm{Na}_{0.3} \mathrm{FeGe}_{2} \mathrm{O}_{6}$ were investigated as function of temperature in range $4 \mathrm{~K}-300 \mathrm{~K}$.

The room temperature crystal structure of $\mathrm{Li}_{0.7} \mathrm{Na}_{0.3} \mathrm{FeGe}_{2} \mathrm{O}_{6}$ is characterized by monoclinic symmetry and space group $C 2 / c$ with parameters $a=10.02346(11), b=8.80980(9), c=$ $5.52550(6) \AA, \beta=108.9286(6)^{\circ}$. $\mathrm{Li}_{0.7} \mathrm{Na}_{0.3} \mathrm{FeGe}_{2} \mathrm{O}_{6}$ is isostructural to $\mathrm{NaFeGe}_{2} \mathrm{O}_{6}$ at $\mathrm{T}=300 \mathrm{~K}$.

The transition from the paramagnetic state to the magnetic long-range ordered state occurring at $\mathrm{T}_{\mathrm{N}}=15.5 \mathrm{~K}$.

Note, the clinopyroxene compounds show a variety of phase crystal structure transitions as a function of temperature. In the case of $\mathrm{LiFeGe}_{2} \mathrm{O}_{6}$ and $\mathrm{Na}_{0.5} \mathrm{Li}_{0.5} \mathrm{FeGe}_{2} \mathrm{O}_{6}$ compounds the changes in symmetry from a low temperature $P 2_{1} / c$ to a high temperature $C 2 / c$ structure were observed at a transition temperature $\mathrm{T}_{\mathrm{tr}}=789 \mathrm{~K}$ and $276 \mathrm{~K}$ correspondingly [10,13]. $\mathrm{NaFeGe}_{2} \mathrm{O}_{6}$ compound exhibits $C 2 / c$ symmetry between 1.6 and $1000 \mathrm{~K}$ [10]. This result indicates that a change in composition of pyroxene-type compounds can have effect on the $P 2_{1} / c \leftrightarrow C 2 / c$ dis- 
placive phase transition. It is not clear the crystal structure of $\mathrm{Li}_{0.7} \mathrm{Na}_{0.3} \mathrm{FeGe}_{2} \mathrm{O}_{6}$ with temperature changes in symmetry or not. It is expected that this pyroxene compound transforms to $P 2_{1} / c$ structure at some low temperatures. The possible magnetic structure depends on crystal structure at low temperatures. In order to further characterize the magnetic state of $\mathrm{Li}_{0.7} \mathrm{Na}_{0.3} \mathrm{FeGe}_{2} \mathrm{O}_{6}$ compound it is necessary the neutron diffraction investigation to determine the magnetic structure.

\section{References}

[1] E.Baum, W.Treutmann, M.Behruzi, W.Lottermoser, G.Amthauer, Structural and magnetic properties of the clinopyroxenes $\mathrm{NaFeSi}_{2} \mathrm{O}_{6}$ and $\mathrm{LiFeSi}_{2} \mathrm{O}_{6}$, FurKristal, 183(1988), 273-284.

[2] G.J.Redhammer, G.Roth, W.Treutmann, M.Hoelzel, W.Paulus, G.Andre, C.Pietzonka, G.Amthauer, The magnetic structure of clinopyroxene-type $\mathrm{LiFeGe}_{2} \mathrm{O}_{6}$ and revised data on multiferroic $\mathrm{LiFeSi}_{2} \mathrm{O}_{6}$, J. Solid State Chem, 182(2009), 2374-2484.

[3] A.N.Vasiliev, O.L.Ignatchik, A.N.Sokolov, Z.Hiroi, M.Isobe, Y.Ueda, Long-range magnetic order in quasi-one-dimensional chromium-based $(\mathrm{S}=3 / 2)$ pyroxenes $(\mathrm{Li}, \mathrm{Na}) \mathrm{Cr}(\mathrm{Si}, \mathrm{Ge})_{2} \mathrm{O}_{6}$, Physical Review B, 72(2005), 012412.

[4] A.N.Vasiliev, O.L.Ignatchik, M.Isobe, Y. Ueda, Long range Néel order in the quasi-onedimensional vanadium-based $(\mathrm{S}=1)$ pyroxenes $(\mathrm{Li}, \mathrm{Na}) \mathrm{V}(\mathrm{Si}, \mathrm{Ge})_{2} \mathrm{O}_{6}$, Physical Review $B$, $\mathbf{7 0}(2004), 132415$.

[5] G.Nenert, C.Ritter, M.Isobe, O.Isnard, A.N.Vasiliev, Y.Ueda, Magnetic and crystal structures of the one-dimensional ferromagnetic chain pyroxene $\mathrm{NaCrGe}_{2} \mathrm{O}_{6}$, Physical Review B, 80(2009), 024402.

[6] T.Drokina, G.Petrakovskii, L.Keller, J.Schefer, Investigation of the magnetic structure in $\mathrm{NaFeGe}_{2} \mathrm{O}_{6}$ using neutron powder diffraction, Journal of Physics: Conference Series, 251(2010), 012016.

[7] G.J.Redhammer, A.Senyshyn, M.Meven, G.Roth, S.Prinz, A.Pachler, G.Tippelt, C.Pietzonka, W.Treutmann, M.Hoelzel, B.Pedersen, G.Amthauer, Nuclear and incommensurate magnetic structure of $\mathrm{NaFeGe}_{2} \mathrm{O}_{6}$ between $5 \mathrm{~K}$ and $298 \mathrm{~K}$ and new data on multiferroic $\mathrm{NaFeSi}_{2} \mathrm{O}_{6}$, Phys. Chem. Miner., 38(2011), 139-158.

[8] G.J. M.Isobe, E.Ninomiya, A.N.Vasiliev, Y.Ueda, Novel Phase Transition in Spin-1/2 Linear Chain Systems: $\mathrm{NaTiSi}_{2} \mathrm{O}_{6}$ and $\mathrm{LiTiSi}_{2} \mathrm{O}_{6}$, J. Phys. Soc. Japan., 71(2002), 1423-1426.

[9] S.V.Streltsov, D.I. Khomskii, Electronic structure and magnetic properties of pyroxenes $(\mathrm{Li}, \mathrm{Na}) \mathrm{TM}(\mathrm{Si}, \mathrm{Ge})_{2} \mathrm{O}_{6}$ : Low-dimensional magnets with $90^{\circ}$ bonds, Physical Review $B$, $77(2008), 064405$.

[10] G.J.Redhammer, F.Cámara, M.Alvaro, F.Nestola, G.Tippelt, S.Prinz, J.Simons, G.Roth, G.Amthauer, Thermal expansion and high-temperature $P 2_{1} / c-C 2 / c$ phase transition in clinopyroxene-type $\mathrm{LiFeGe}_{2} \mathrm{O}_{6}$ and comparison to $\mathrm{NaFe}(\mathrm{Si}, \mathrm{Ge})_{2} \mathrm{O}_{6}$, Phys. Chem. Miner., 37(2010), 685-704.

[11] L.Solovyova, V.Bakakin, X-ray investigation of $\mathrm{Na}$, Fe-metagermanate $\mathrm{NaFeGe}_{2} \mathrm{O}_{6}$, Krystallographiya, 12(1967), 591-594 (in Russian). 
[12] T.V.Drokina, G.A.Petrakovskii, L.Keller, J.Schefer, A.D.Balaev, A.V. Kartashev, D.A.Ivanov, Modulated magnetic structure in quasi-one-dimensional clinopyroxene $\mathrm{NaFeGe}_{2} \mathrm{O}_{6}$, Journal of Experimental and Theoretical Physics, 112(2011), 121-126 (in Russian).

[13] T.V.Drokina, G.A.Petrakovskii, M.S.Molokeev, S.V.Misyul, V.S.Bondarev, D.A.Velikanov, M.Frontzek, J.Schefer, Crystal and magnetic structures, phase transitions in quasi-onedimensional pyroxenes $\mathrm{Na}_{0.5} \mathrm{Li}_{0.5} \mathrm{FeGe}_{2} \mathrm{O}_{6}$, Journal of Magnetism and Magnetic Materials, 385(2015), 243.

[14] Bruker AXS TOPAS V4: General profile and structure analysis software for powder diffraction data, User's Manual, Bruker AXS, Karlsruhe, Germany, 2008.

[15] T.V.Drokina, O.A.Bayukov, G.A.Petrakovskii, D.A.Velikanov, A.F. Bovina, G.N.Stepanov, D.A.Ivanov, Synthesis and properties of $\mathrm{NaFeGe}_{2} \mathrm{O}_{6}$ polycrystals, Fizika Tverd. Tela, 50(2008), 2050-2053 (in Russian).

\section{Структурные и магнитные свойства пироксена $\mathrm{Li}_{0.7} \mathrm{Na}_{0.3} \mathrm{FeGe}_{2} \mathrm{O}_{6}$}

Тамара В. Дрокина Герман А. Петраковский Дмитрий А. Великанов Максим С. Молокеев Елена Г. Резина

\footnotetext{
Поликристаллические образцы $\mathrm{Li}_{0,7} \mathrm{Na}_{0,3} \mathrm{FeGe}{ }_{2} \mathrm{O}_{6}$ были получены твердофазным синтезом и исследованы методами рентгеновской дифракиии и СКВИД-метрии. Представлены характеристики структурных свойств. Показано, что температурная зависимость магнитной восприимчивости при температуре 15,5 К имеет излом, характерный для переходов в магнитоупорядоченное состояние.
}

Ключевые слова: твердый раствор, пироксен, кристаллическая структура, магнитные свойства. 